\title{
Strategi Guru Dalam Mengembangkan Resolusi Konflik Pada Anak Usia Dini Dalam Rangka Menyongsong Masyarakat 5.0
}

\author{
Rosyi Damayanit. Maningtyas \\ Universitas Negeri Malang \\ Email: rosyi.damayani.fip@um.ac.id
}

\section{Eny Nur Aisyah}

Universitas Negeri Malang

Email: Eny.nur.fip@um.ac.id

\section{Tumardi}

Universitas Negeri Malang

Email: tumardi.fip@um.ac.id

Article received: 06 Desember 2020, Review process: 27 Februari 202021,

Article Accepted: 19 Maret 2021, Article published: 30 Maret 2021

\begin{abstract}
This study aims to find out how the perceptions of young children teachers to the development of conflict resolution for early childhood and how the teachers' strategies in developing conflict resolution skills in early childhood. This research uses descriptive quantitative method. The instrument used for data collection was a questionnaire distributed online. The result of this research is that teachers in Malang City have the right and correct perceptions about conflict resolution taught in early childhood. the majority of paud teachers in Malang city have implemented appropriate strategies in developing conflict resolution skills in early childhood.
\end{abstract}

Keywords : perception; strategy; conflict resolution; early childhood

\begin{abstract}
Abstrak
Penelitian ini bertujuan untuk mengetahui bagaimana persepsi guru paud terhadap pengembangan resolusi konflik bagi anak usia dini dan bagaimana strategi guru dalam mengembangkan kemampuan resolusi konflik pada anak usia dini. penelitian ini menggunakan metode deskriptif kuantitatif. Instrument yang digunakan untuk pengumpulan data adalah kuisioner yang disebarkan secara online. Hasil dari penelitian ini adalah guru- guru di kota malang memiliki persepsi yang tepat dan benar mengenai resolusi konflik yang diajarkan pada anak usia dini. Mayoritas guru paud di kota malang telah menjalankan strategi- strategi yang sesuai dalam mengembangkan kemampuan resolusi konflik pada anak usia dini.
\end{abstract}

Kata Kunci: persepsi; strategi; resolusi konflik; anak usia dini,

\section{PENDAHULUAN}

Konflik merupakan hal yang lumrah terjadi dalam kehidupan manusia. Konflik terjadi (Wahyudi 2015) kebudayaan dan semakin majunya teknologi berdampak pula pada perkembangan kebutuhan dan kepentingan manusia. Hal ini kemudian menimbulkan berbagai perbedaan dalam dimensi-dimensi kehidupan 
manusia. Adanya perbedaan- perbedaan di kalangan kelompok manusia mau tidak mau akan menimbulkan gesekan kepentingan. Gesekan kepentingan ini jika terus dibiarkan akan menghasilkan disharmoni dan disintegrasi yang pada akhirnya berubah menjadi konflik. Terjadinya konflik lebih disebabkan oleh egoisme manusia dalam memenuhi kepentingannya sehingga menabrak kepentingan manusia lainnya (Dalimunthe 2014).

Tidak hanya pada kehidupan manusia dewasa, konflik juga dapat terjadi dalam kehidupan anak usia dini. Anak usia dini yang menurut Piaget tengah berada dalam masa pra operasional dan operasional kongkrit memiliki karakteristik yang khas dalam pola pikirnya, yaitu karakter egosentris (Juwantara 2019). Pola pikir egosentris ini menyebabkan anak usia dini tidak jarang menabrak kepentingan rekan sebayanya demi meraih apa yang dia inginkan. Keadaan inilah yang kemudian menjadi awal dari konflik anak usia dini. Konflik yang terjadi pada masa usia dini seringkali berupa, perebutan mainan, perebutan posisi tempat duduk, penyerangan saat sedang bermain, atau juga perdebatan karena perbedaan pilihan atau pendapat.

Pada masa usia dini konflik sering terjadi karena anak-anak sering memiliki ide yang jelas tentang apa yang mereka inginkan, tetapi mereka tidak tahu bagaimana mendapatkan apa yang mereka inginkan tersebut dengan cara yang dapat diterima secara sosial atau dengan cara yang oleh teman-teman mereka akan diakui sebagai hal yang sah (Lang 2016). Pada poin inilah keberadaan guru sangat penting untuk hadir dalam proses penyelesain konflik anak usia dini. Anak usia dini merasa tersakiti dalam konflik namun tidak mengetahui bagaimana cara keluar dari situasi tersebut dan maju terus. Keadaan yang demikian ini menyebabkan konflik di masa usia dini cenderung menguap begitu saja karena tidak adanya upaya untuk menyelesaikan sejak dini (Nurjannah 2017). Orang tua, khususnya yang kurang memahami pendidikan anak usia dini cenderung beranggapan bahwa saat dewasa anak akan tahu dengan sendirinya bagaimana bersikap dewasa, sehingga pembelajaran tentang resolusi konfik cenderung tidak menjadi perhatian.

Pengembangan kemampuan resolusi konflik menjadi aspek yang penting untuk dikembangkan. Kemampuan resolusi konflik memberikan peluang kepada anak untuk dapat menghadapi konflik sosial secara berani dan sehat sejak dini. Tidak berkembangnya kemampuan resolusi konflik pada diri manusia akan berdampak pada ketidakmampuan mengelola konflik sosial yang merupakan aspek penting dalam kecerdasan interpersonal (Anon 2012). Akibatnya berkembang manusia manusia yang cenderung suka menciptakan konflik atau memelihara konflik. Fenomena yang terjadi dewasa ini membuktikan bahwa masyarakat milenial belum memiliki kemampuan resolusi konflik yang baik. Adanya kebiasaan masyarakat dunia maya yang dengan mudah mencela dan berkomentar provokatif menjadikan semakin maraknya konflik sosial yang terjadi di masyarakat (Riyanto 2019). Dewasa ini bahkan berkembang kebiasaan saling lapor yang justru semakin memperuncing masalah alih alih menyelesaikannya.

Tahap paling awal dalam upaya pengembangan resolusi konflik khususnya pada anak usia dini adalah mengetahui persepsi guru PAUD mengenai resolusi konflik. Bagi anak usia dini, guru adalah pemandu arah bagi mereka. Memahami persepsi guru PAUD tentang resolusi konflik akan memandu kita pada pemahaman mengenai Tindakan- Tindakan apa saja yang mungkin untuk dilakukan. 
Sebagaimana yang diketahui bersama, persepsi seorang guru akan menuntun sikapnya terhadap sesuatu. Mengetahui persepsi seorang guru dapat menjadi prediksi awal bagaimana melihat perkembangan Pendidikan resolusi konflik di masa usia dini.

Penelitian ini bertujuan untuk mengetahui persepsi guru PAUD dalam pengembangan kemampuan resolusi konflik bagi anak usia dini. guru adalah ujung tombak dalam pengembangan kemampuan ini. Mengetahui bagaimana persepsi guru artinya mengetahui apakah guru- guru PAUD telah berada pada jalur yang benar mengenai konsep resolusi konflik.

\section{METODOLOGI}

Penelitian ini menerapkan pendekatan penelitian kuantitatif deskriptif. Penelitian ini dilakukan untuk mengetahui sejauh mana persepsi guru PAUD dalam mengembangkan kemampuan resolusi konflik anak usia dini yang didiknya. Populasi dari penelitian ini adalah guru-guru PAUD Kota Malang. Peneliti menggunakan Teknik random sampling untuk mendapatkan 65 guru untuk menjadi sample. Penelitian ini dilakukan antara bulan Agustus sampai dengan oktober 2020 di kota Malang. Data dari Penelitian ini adalah data mengenai persepsi guru terhadap pengembangan resolusi konflik pada anak usia dini. untuk dapat mengumpulkan data ini, peneliti menyusun pertanyaan pertanyaan penelitian yang didasarkan pada indikator-indikator berikut : a) persepsi terhadap konflik AUD b) sikap terhadap konflik AUD, c) persepsi intensitas terjadinya konflik AUD, d) persepsi terhadap bullying, f) intensitas terjadinya bullying, g) persepsi terhadap penyelesaian konflik, h) persepsi terhadap kemampuan AUD menyelesaikan konflik. Pengumpulan data dilakukan menggunakan kuisioner yang dibagikan kepada 65 guru yang menjadi sample penelitian. Data yang diperoleh kemudian disusun dan disajikan untuk kemudian dilakukan analisis data. Analisis data pada penelitian ini menggunakan analisis persentase, dimana peneliti melakukan perhitungan terhadap sebaran jawaban yang dibuat responden dalam kuisioner pengumpul data. Adapun rumusan analisis datanya adalah sebagai berikut :

$$
\text { Persentase }=\frac{\text { frekuensi munculnya respon }}{\text { frekuensi keseluruhan responden }} \times 100 \%
$$

Setelah data selesai dianalisis, peneliti melakukan interpertasi terhadap data yang diperoleh untuk kemudian disusun suatu kesimpulan. Responden pada penelitian ini merupakan guru-guru yang tergabung dalam Ikatan Guru TK dan PAUD Indonesia. Sebelum menjadi responden penelitian, para guru telah terlebih dahulu menyatakan kesediaan mereka untuk menjadi responden penelitian secara sukarela. Penelitian ini diharapkan menjadi refleksi bagi para responden khususnya dan para pendidik paud pada umumnya untuk memastikan sejauh mana pengembangan resolusi konflik telah dikembangkan.

\section{HASIL DAN PEMBAHASAN \\ Persepsi Guru PAUD mengenai Pengembangan Resolusi Konflik}

Persepsi merupakan hal yang penting untuk diperhatikan. Karena persepsi akan menentukan sikap individu terhadap sesuatu. Hampir seluruh tingkah laku seseorang ditentukan oleh sikapnya, dan sikap seseorang ditentukan oleh 
persepsinya. Dalam konteks pengembangan resolusi konflik pada anak usia dini, persepsi guru memegang peranan yang sangat penting. Menurut Sarwono dalam Listiyana \& Hartono (Listyana 2015), persepsi diartikan sebagai proses dalam memperoleh, menafsirkan, pemilihan, dan pengaturan informasi inderawi. Menurut Gibson \& Donely, persepsi merupakan proses pemberian arti terhadap pengalaman- pengalaman individu di lingkungannya (Setiawan n.d.). Dalam hal ini, persepsi guru dalam mengembangkan resolusi konflik diartikan sebagai sebuah proses dari seorang guru untuk memaknai konflik pada anak usia dini yang diperoleh melalui indera para guru PAUD. Persepsi ini berikutnya akan tercermin dalam sikap dan Tindakan yang dilakukan guru terhadap konflik yang terjadi diantara anak usia dini (Zuchdi 1995).

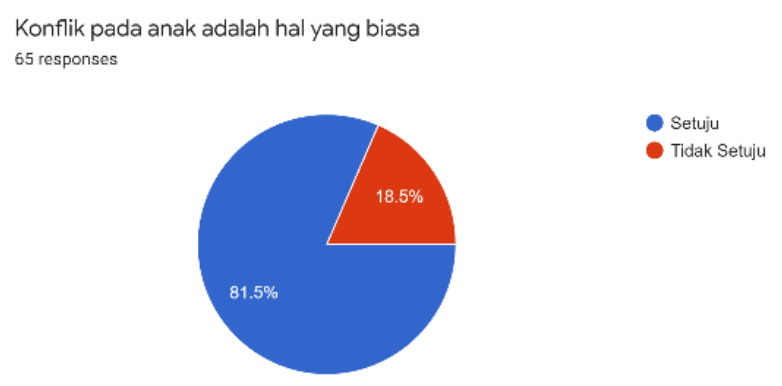

Gambar 1. Persepsi Guru terhadap Konflik

Berdasarkan hasil pengumpulan data seperti pada gambar 1, diketahui bahwa $81,5 \%$ dari 65 guru yang diteliti memiliki persepsi bahwa konflik biasa terjadi kepada anak. Hal ini memberikan konsekuensi bahwa guru- guru PAUD memiliki sikap yang tidak apatis atas terjadinya konflik pada anak usia dini (Alang 2014). Para guru memiliki kecenderungan untuk tidak panik saat mengetahui anak usia dini mengalami konflik dengan sesamanya. Persepsi ini juga mengandung konsekuensi sikap negatif dimana dapat dimungkinkan kecenderungan untuk membiarkan terjadinya konflik pada anak karena adanya anggapan bahwa konflik wajar terjadi pada pergaulan anak usia dini.

Dari data di atas juga diketahui bahwa, sekitar $18,5 \%$ dari 65 orang guru yang diteliti memiliki persepsi bahwa konflik pada anak bukan merupakan hal yang wajar. Persepsi ini akan membawa konsekuensi sikap yang cenderung anti konflik. Persepsi yang demikian ini cenderung menjadikan guru mudah panik saat mengetahui anak didiknya berkonflik dengan teman sebaya mereka (Sudrajat 2014).

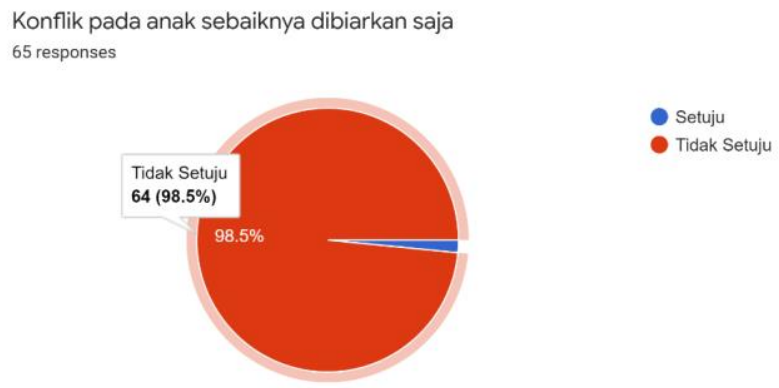

Gambar 2. Sikap Guru Saat Menghadapi Konflik Anak 
Berdasarkan hasil analisis data seperti yang tersaji pada gambar 2, diketahui bahwa $98,5 \%$ guru memiliki persepsi bahwa konflik pada anak tidak dapat dibiarkan saja. Dari data ini dapat kita ketahui bahwa guru-guru di kota malang telah memiliki komitmen untuk memberikan bimbingan mengenai resolusi konflik pada anak usia dini. Data ini juga menunjukkan bahwa persepsi guru mengenai sikap saat menemui konflik pada anak mengindikasikan bahwa guru siap hadir dan terlibat dalam upaya mengajarkan anak bagaimana melakukan resolusi konflik yang tepat dan berbasis win- win solution. Guru memahami bahwa meski konflik hal yang biasa terjadi diantara anak- anak, namun anak- anak tetap membutuhkan kehadiran guru dalam menghadapinya, alih-alih membiarkan anak menyelesaikannya sendiri. Sikap ini memberikan dampak positif pada kepercayaan diri anak karena dengan kehadiran guru, penyelesaian konflik dapat diharapkan terselesaikan secara adil.

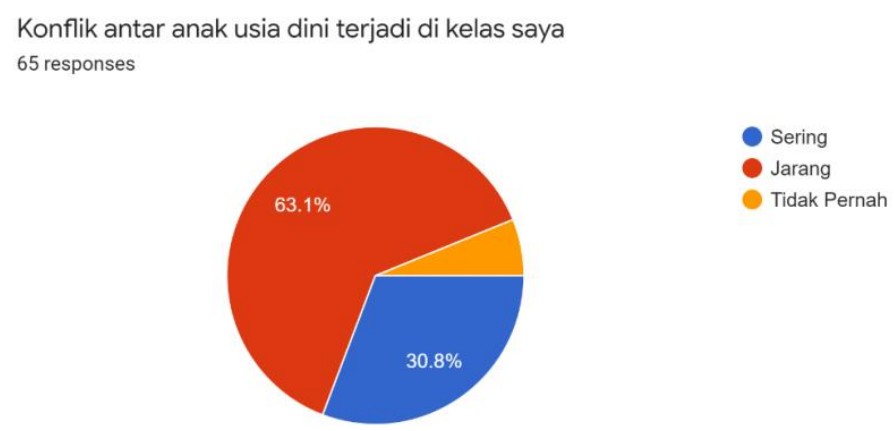

Gambar 3. Intensitas Terjadinya Konflik

Berdasarkan hasil pengumpulan data seperti pada gamber 3 , diketahui bahwa sebanyak 30,8\% dari responden guru melaporkan bahwa konflik antar anak usia dini sering terjadi di dalam kelas. Hal ini menjadi penguatan bahwa konflik memang cenderung dialami oleh anak. Anak cenderung mengalami konflik dengan teman sebayanya karena dari segi perkembangan kognitif Piaget, anak berada pada tahap perkembangan praoperasional (Khaironi 2018). Tahap perkembangan pra operasional pada anak terjadi di usia prasekolah, yang mana salah satu karakteristik utama pada tahap ini adalah cara berpikir yang egosentris. Pola pikir yang egosentris merupakan cara berpikir anak usia dini yang melihat segala sesuatu dari sudut pandangnya sendiri dan kesulitan untuk memahami sudut pandang orang lain. Pola berpikir seperti ini merupakan pola berpikir yang rentan terhadap konflik. Hal ini dikarenakan konflik umumnya terjadi karena adanya perebutan kepentingan yang mana tidak ada kesepahaman situasi antara dua pihak yang terlibat konflik (Wardyaningrum 2013) . Salah satu pemicu konflik adalah adanya egosentrisme dari pihak- pihak yang berkonflik untuk mempertahankan kepentingannya. Meski demikian, berdasarkan data di atas dapat diketahui bahwa masih banyak kelompok anak usia dini yang jarang mengalami konflik dalam kehidupan sehari- harinya. Hal ini dapat disebabkan oleh banyak faktor. Salah satunya dapat disebabkan oleh keberhasilan guru dalam membimbingkan resolusi konflik bagi anak usia dini sehingga anak dapat menyelesaikan konflik yang terjadi sebelum mendapat bantuan guru. Ketiadaan konflik yang terjadi di kelas- kelas paud juga dapat disebabkan oleh kurang nya 
interaksi yang terjadi antar anak usia dini sehingga tidak terjadi konflik diantara mereka. Hal ini dapat terjadi apabila masing- masing anak usia dini dibekali dengan mainan atau kesibukan masing- masing yang bersifat individual sehingga mereka tidak memiliki cukup waktu untuk berinteraksi maupun berkonflik.

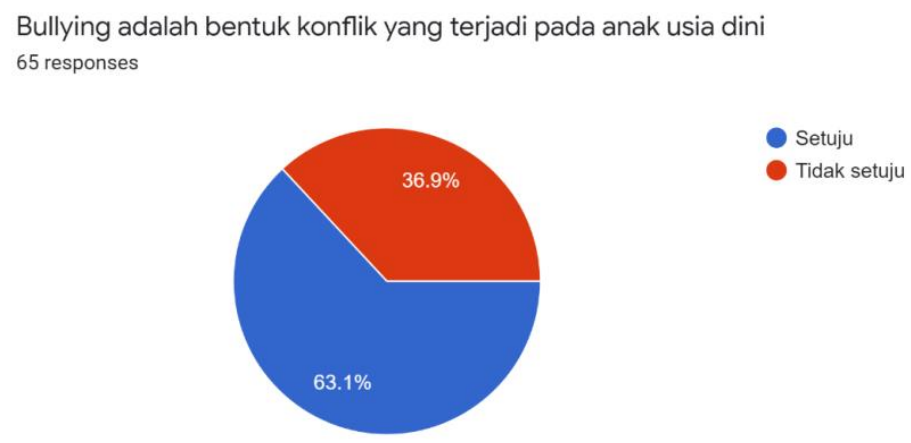

\section{Gambar 4. Persepsi Guru terhadap Bullying}

Bullying merupakan bentuk kompleks dari konflik yang terjadi pada pergaulan anak- anak. Awal mula terjadinya bullying adalah karena adanya konflik antar golongan sebaya diantara anak usia dini. Pada penelitian ini diperoleh data mengenai persepsi guru terhadap bullying. Dari 65 guru yang diteliti, diketahui bahwa $63,1 \%$ guru sepakat bahwa bullying merupakan bentuk konflik yang terjadi pada anak usia dini. Menurut Stephanie Mihalas dalam (Parenting 2020) menyatakan bahwa bentuk bullying yang terjadi di level pra sekolah atau SD kelas awal umumnya lebih jelas terlihat dalam bentuk ejekan atau diskriminasi pergaulan. Berdasarkan data di atas diketahui bahwa $36,9 \%$ responden guru yang diteliti menyatakan bahwa bullying bukan merupakan bentuk konflik yang terjadi pada anak usia dini. Hal ini bisa terjadi dikarenakan adanya anggapan bahwa tidak mungkin terjadi bullying di level Pendidikan anak usia dini. anak usia dini dianggap terlalu muda untuk mengerti tentang bullying. Namun, pemahaman ini belum dapat dikatakan tepat, karena dewasa ini arus informasi sangatlah deras termasuk mempengaruhi anak usia dini. anak usia pra sekolah bukan tidak mungkin mendapat model atau contoh dari perilaku bulliying melalui internet atau acara televisi seperti sinetron atau film pendek. Oleh karena itu sebaiknya sebagai pendidik memang harus senantiasa berhati- hati atas segala kemungkinan yang bisa menganggu perkembangan peserta didik.

Bullying terjadi di kelas saya
65 responses

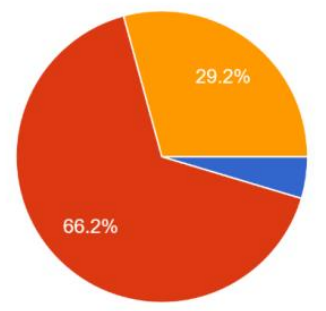

Sering

Jarang

Tidak Pernah

Gambar 5. Persepsi Guru Tentang Intensitas Kejadian Bullying 
Sebagaimana telah dijelaskan di atas bahwa bulliying yang terjadi pada tingkat pra sekolah umumnya sangat mudah untuk diketahui. Menurut Dr. Ostrove dalam (Parenting 2020) terdapat 3 bentuk bullying yang bisa terjadi pada kelompok anak usia dini. Pertama, physical bullying, yaitu perundungan yang terjadi dalam bentuk kekerasan fisik, seperti memukul, menendang, mengambil sesuatu dari anak lain, dan sejenisnya. Bentuk kedua adalah social bullying atau relasional, yaitu perundungan yang dilakukan dalam bentuk menyebarkan gossip atau mengucilkan anak lain. Berdasarkan hasil analisis data yang terdapat pada gambar 5, diketahui bahwa Tindakan bullying jarang terjadi di tingkat PAUD. Sebuah kondisi yang patut disyukuri. Kondisi ini terjadi karena bentuk bullying di tingkat PAUD sangat mudah terlihat sehingga mudah dicegah. Jika sampai tindakan bullying terjadi pada anak umumnya ditandai dengan perilaku- perilaku seperti selalu terlihat sedih, kehilangan nafsu makan, tidak mau ke sekolah, mengalami perubahan tingkah laku, atau beberapa kali kehilangan barang saat pulang sekolah. Meski hanya 3,4\% guru yang melaporkan hal yang demikian ini, sebagai pendidik sepatutnya waspada atas potensi-potensi kejadian bullying di sekitar kita.

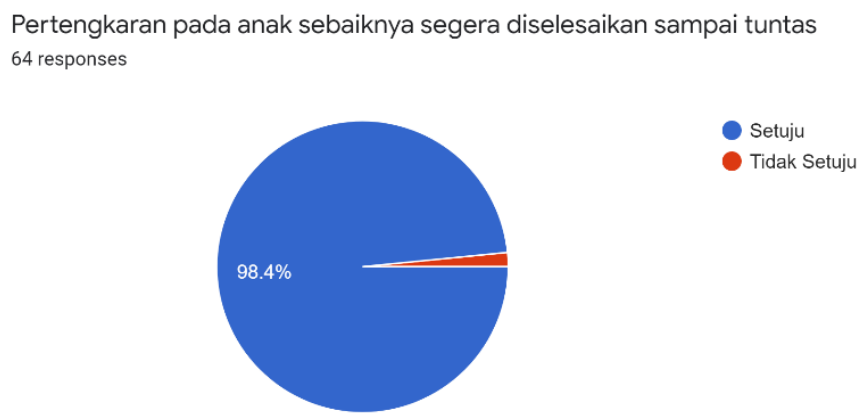

Gambar 6. Persepsi terhadap Penyelesaian Konflik

Berdasarkan hasil Analisa yang terlihat pada gambar 6 , diketahui bahwa sebanyak $98 \%$ persepsi guru terhadap pertengkaran atau konflik yang terjadi di kalangan anak- anak adalah harus diselesaikan. Artinya guru harus hadir dalam konflik yang terjadi. Hampir seluruh guru memliki keyakinan bahwa setiap konflik harus diselesaikan secara tuntas, artinya setiap anak yang berkonflik harus dibimbing untuk menghadapi konflik yang dialami dan menyelesaikannya sehingga tidak adalagi kemarahan yang tersisa untuk dirasakan oleh masingmasing pihak yang berkonflik. Hal ini sebenarnya cukup mudah dilakukan pada masa usia dini. anak usia dini yang cenderung memiliki cara pandang egosentris akan berfokus pada apa yang mereka ingin lakukan, sehingga ketika kedua anak yang berkonflik menemukan kebutuhan baru yang mana kebutuhan baru tersebut menuntut mereka untuk berinteraksi bersama, maka konflik yang terjadi diantara mereka sebelumnya akan terlupakan. Namun, meski anak mudah melupakan konflik yang terjadi diantara mereka, orang tua dan guru tetap harus mengajarkan cara untuk menuntaskan konflik mereka sehingga di kemudian hari anak tidak takut menghadapi konflik yang ada dalam kehidupannya serta menghadapi 
Pertengkaran pada anak selalu dapat diselesaikan sendiri oleh anak 64 responses

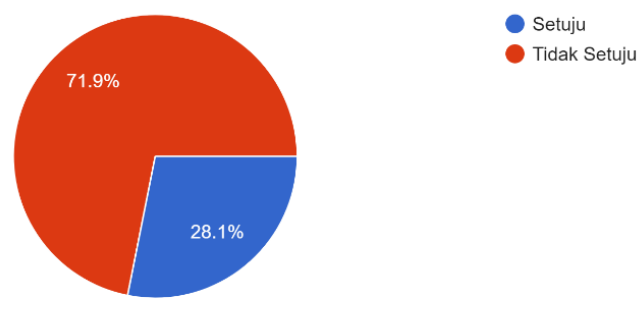

Gambar 7. Persepsi terhadap Kemampuan Anak Menyelesaikan Konflik

Berdasarkan hasil Analisa pada gambar 7, diketahui bahwa $71.9 \%$ guru PAUD memiliki persepsi bahwa anak- anak tidak akan mampu menyelesaikan konflik yang mereka alami sendiri. Hal ini dapat dikarenakan oleh masih tingginya egosentrisme yang dimiliki anak- anak dan tahap perkembangan kognitif anak usia dini yang belum sampai pada kematangan menyelesaikan konflik. Oleh karena itu anak membutuhkan bantuan untuk mempelajari bagaimana menghadapi dan menyelesaikan konflik yang terjadi pada mereka. Mengajarkan anak-anak cara menyelesaikan konflik bagaikan menulis pada kertas kosong. Hal tersebut merupakan hal baru bagi anak- anak sehingga tidak mudah untuk diajarkan. Mengajarkan manajemen konflik membutuhkan kesabaran dan pembiasaan. Berdasarkan data yang telah diperoleh sebanyak $28,1 \%$ guru memiliki persepsi bahwa anak dapat menyelesaikan sendiri konflik yang mereka alami. Hal ini dapat terjadi karena guru beranggapan bahwa apabila anak- anak yang tengah berkonflik telah dapat saling berinteraksi kembali sebagaimana semula, maka hal tersebut dapat diartikan bahwa konflik telah selesai. Hal ini tidak salah tapi tidak sepenuhnya tepat, karena dengan memiliki persepsi seperti ini, guru akan cenderung terlena untuk mengajarkan anak- anak cara menghadapi konflik.

Berdasarkan uraian di atas dapat disimpulkan bahwa Sebagian besar guru- guru di kota malang telah memiliki persepsi yang tepat tentang pengembangan resolusi konflik sejak masa usia dini. Para guru berpandangan bahwa konflik pada masa usia dini adalah hal yang wajar sehingga tidak perlu disikapi dengan kepanikan. Namun, konflik pada anak juga hendaknya tidak dibiarkan. Guru maupun orang dewasa perlu membantu anak untuk dapat menyelesaikan konflik yang dihadapi hingga tuntas. Kehadiran guru dalam konflik yang terjadi diantara anak- anak akan membantu mereka mempelajari keterampilan hidup yang disebut dengan resolusi konflik. Persepsi guru ini akan mendasari perilaku mereka dalam mengembangkan kemampuan resolusi konflik anak usia dini.

\section{Strategi Pengembangan Resolusi Konflik pada Anak Usia Dini}

Salah satu skill penting yang harus dimiliki anak usia dini , khususnya masa pra sekolah untuk mencapai interaksi sosial yang sukses adalah kemampuan untuk meresolusi konflik. Ketika guru dan orang tua mengajarkan anak kemampuan meresolusi konflik, Sesungguhnya mereka tengah menyiapkan anak-anak untuk dapat mencegah situasi berada di luar kontrol mereka. $\underline{\text { Kemampuan ini sangat penting dimiliki untuk mengembangkan dan membangun }}$ 
hubungan dengan orang lain (Agarwal 2000). Resolusi konflik bagi anak usia dini merupakan hal yang abstrak. Tantangan yang dihadapi oleh anak tidak hanya dari lingkungannya, tetapi juga dari dalam diri mereka sendiri. Dari lingkungan tentu setiap interaksi sosial akan berpotensi konflik, khususnya interaksi dengan teman sebaya. Adapun tantangan dari dalam diri anak anak sendiri adalah pola pikir egosentris yang membuat anak akan kesulitan mengerti keadaan orang lain. Sebagaimana yang disampaikan oleh (Eighty Six 2014) yang menyatakan bahwa anak- anak ,di masa pra sekolah khususnya, berada pada masa transisi yang besar dimana mereka mengalami perubahan dari dunia balita ke dunia anakanak. Dunia balita adalah dunia dimana mereka mnejadi pusat perhatian. Dunia anak- anak yang mana mereka mulai bertemu dengan sebaya mereka dan memiliki kemampuan yang relatif sama dengan mereka. Pada situasi ini anak diharapkan mampu hidup berdampingan dengan anak lain, mampu berbagi, dan menemukan identitas mereka. Tentu saja hal ini tidak akan mungkin mampu dicapai anak dalam sekejap. Untuk bisa hidup berdampingan dengan orang lain, berbagi, dan memiliki identitas, anak-anak harus dapat menemukan jawaban dari pertanyaan-pertanyaan seperti: apa yang harus dilakukan saat seseorang menyakiti mereka?, bagaimana jika mereka menginginkan sesuatu yang menjadi milik orang lain?, bagaimana jika orang lain mengambil sesuatu milik mereka?, bagaimana mereka menangani raksasa emosi yang mereka rasakan utamanya saat berkonflik dengan anak lain. Untuk dapat menemukan jawabannya, anakanak membutuhkan bantuan dari orang dewasa.

Untuk dapat membantu anak- anak mengembangkan resolusi konflik, guru dapat menggunakan 2 strategi pengembangan resolusi konflik. Strategi pertama adalah strategi resolusi sebelum konflik dan strategi kedua adalah strategi penanganan konflik. Penelitian ini mengkaji tentang sejauh mana strategi resolusi konflik ini telah dilakukan oleh guru-guru di kota malang. Adapun hasil dari penelitian ini adalah sebagai berikut:

\section{Strategi Resolusi Sebelum Konflik}

Strategi pencegahan konflik dapat dilakukan dengan berbagai cara oleh guru. Tim peneliti merangkum setidaknya terdapat 5 strategi yang dapat dijalankan untuk mengajarkan resolusi konflik yaitu: mengajak anak mengenali emosinya secara verbal, memberikan anak materi yang mendorong berlatih pemecahan masalah, mendiskusikan cara menghadapi konflik, memperagakan cara mengatasi konflik, memberi contoh cara mengatasi konflik yang tepat. Berkaitan dengan tindakan di atas, hasil penelitian ini menunjukkan sebagai berikut :

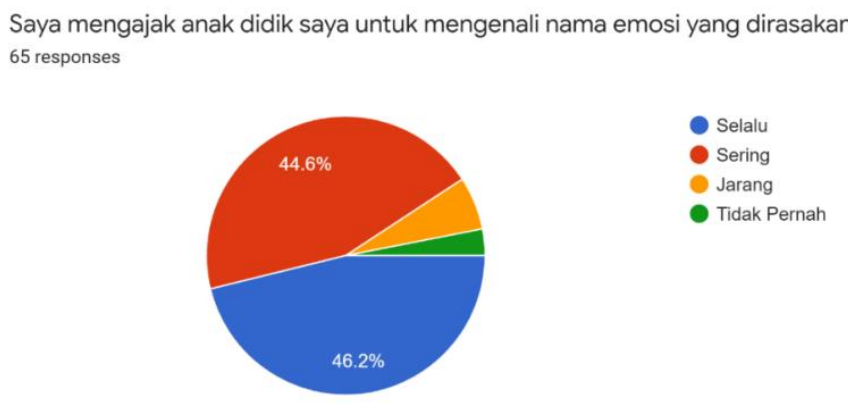

Gambar 8. Mengajak Anak Mengenali Emosinya 
Berdasarkan hasil analisis yang terlihat pada gambar 8, diketahui bahwa sebanyak $46,2 \%$ guru telah berusaha untuk selalu mengajarkan pada anak cara mengenali emosinya. Dan $44,6 \%$ menyatakan sering mengajarkan anak cara mengenali emosinya. Sisanya, yaitu sekitar $9 \%$ guru menyatakan tidak atau jarang mengajarkan anak cara mengenali emosinya.

Hasil ini menunjukkan bahwa sebagian besar guru paud di kota malang telah melakukan langkah awal dalam membantu anak melakukan resolusi konflik dengan cara melatih anak mengenali emosinya. Latihan mengenal emosi sangatlah penting bagi anak usia dini, karena sebagaimana yang dikatakan oleh Brighthub Education dalam (Eighty Six 2014) bahwa anak- anak terlahir dalam keadaan tidak tahu. Maka orang dewasalah yang membantu dia mengenal banyak hal. Berdasarkan apa yang disampaikan oleh Golleman dalam (Sa'diyah 2018) bahwa pengenalan emosi merupakan tahap awal dalam membangun kecerdasan emosi individu. Kecerdasan emosi akan membantu seseorang dalam mengembangkan potensinya lebih jauh, memiliki kemampuan membangun hubungan yang positif dengan orang lain, dan mengembangkan kemampuan pemecahan masalah. Adapun kemampuan pemecahan masalah adalah kemampuan yang sangat dibutuhkan dalam mengembangkan kemampuan resolusi konflik.

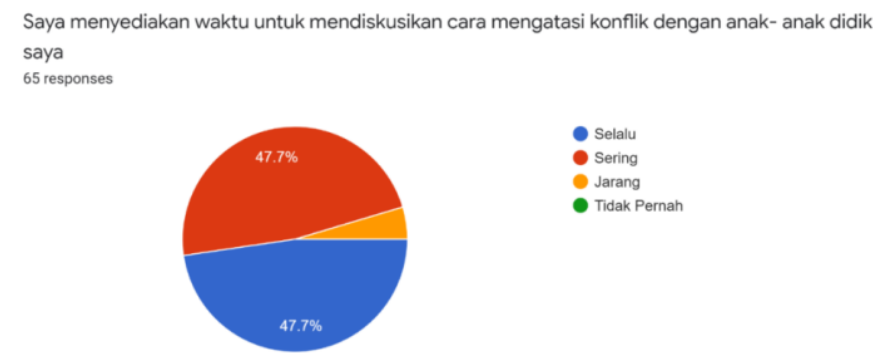

Gambar 9. Memberikan Materi dan Mendiskusikan Resolusi Konflik

Hampir sebagaian besar guru menunjukkan komitmen mengembangkan kemampuan resolusi konflik anak didik mereka dengan memberikan materi dan mendiskusikan tentang resolusi konflik. Langkah ini merupakan langkah yang penting dimana dalam moment ini guru dapat memberikan pembekalan kepada peserta didik sebelum mereka mengalami konflik itu sendiri. Dalam penelitian ini diketahui bahwa hanya $4,3 \%$ guru yang belum fokus melakukan pembekalan khusus terhadap peserta didiknya. Hal ini bisa disebabkan oleh belum munculnya kesadaran tentang pentingnya membekali anak dengan kemampuan resolusi konflik.

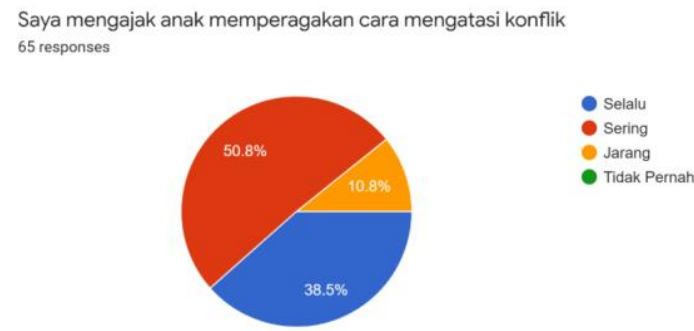

Gambar 10. Mengajak Anak Bermain Peran 
Mengajak anak memperagakan cara mengatasi konflik adalah salah satu langkah yang tepat dalam mengembangkan resolusi konflik pada anak usia dini. Sebagaimana diketahui bermain peran merupakan strategi yang efektif dalam melatih pikiran dan perasaan kompleks (Ningsih 2019). Penggunaan metode bermain peran bagi anak usia dini membantu anak usia dini membuat relasi antara dunia imajinasi dengan dunia nyata. Sehingga pemahaman anak tentang resolusi konflik akan semakin mantap.

Saya memberikan contoh cara mengatasi konflik yang tepat pada anak- anak didik saya. 65 responses
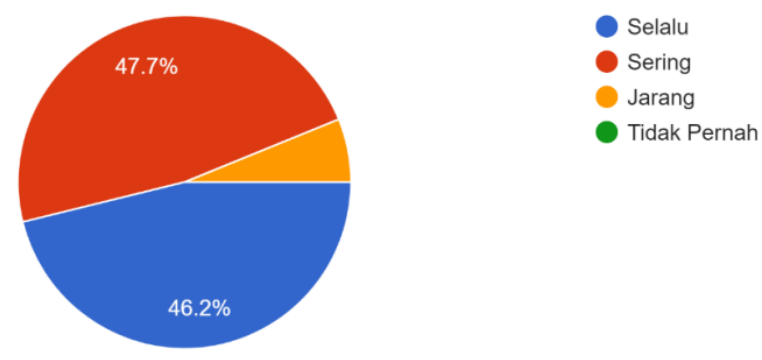

Gambar 11. Mencontohkan Secara Langsung

Berdasarkan hasil analisis data yang tersaji pada gambar 11, diketahui bahwa Sebagian besar guru memberikan contoh secara langsung bagaimana cara melakukan resolusi konflik. Contoh ini sangat penting bagi anak usia dini karena anak usia dini masih berada dalam tahap perkembangan berpikir kongkrit. Mereka tidak akan bisa memahami cara melakukan resolusi konflik bila terlebih dahulu tidak diperagakan atau dicontohkan oleh guru (Amini 2014). Dalam memahami resolusi konflik anak sedang melakukan perubahan gaya berpikir dari kongkrit menjadi abstrak. Untuk dapat melakukan hal tersebut anak membutuhkan pengalaman.

\section{Strategi Penanganan Konflik}

Konflik merupakan hal yang penting untuk dialami anak usia dini. dalam konflik anak belajar untuk mempertahankan dirinya. Memperhatikan kondisi orang lain adalah tugas perkembangan selanjutnya. Saat terjadi konflik anak akan cenderung mengikuti insting alamiahnya yaitu antara melarikan diri atau menghadapinya secara frontal dan acak. Pada umumnya kecenderungan alamiah ini akan mengarah pada tindakan-tindakan anarkis jika tidak segera diarahkan. Peran guru sangatlah penting untuk mengarahkan Tindakan anak sekaligus mengajarkan resolusi konflik agar Tindakan- Tindakan yang diluar kontrol dapat dihindari (Darmadi 2015). Terdapat setidaknya enam strategi yang dapat dilakukan guru untuk mengajarkan resolusi konflik pada anak usia dini saat konflik tepat terjadi. Enam strategi tersebut adalah Mendekati lokasi terjadinya konflik, Mendengarkan semua sisi konflik, Mendorong anak untuk memecahkan masalah, Mengajarkan anak cara memecahkan permasalahan, Mengamati anak dalam menunjukkan pl mengatasi konflik, Memberikan pujian atas keberhasilan siswa mengatasi konflik (Eighty Six 2014).

Penelitian ini melakukan survei kepada 65 guru PAUD mengenai bagaimana strategi mereka mengajarkan strategi resolusi konflik pada anak usia 
dini, khususnya usia pra sekolah. Hasil penelitian menunjukkan hampir sebagian besar guru melaksanakan keenam strategi resolusi konflik di atas. Hal ini berarti secara umum guru-guru di TK Malang telah mengembangkan kemampuan resolusi konflik anak usia dini dengan strategi yang tepat. Hanya saja berdasarkan hasil penelitian, tampak bahwa guru masih menggunakan pendekatan berpusat pada guru dalam membantu anak mengembangkan kemampuan resolusi konflik mereka. Guru banyak memberikan arahan langsung mengenai solusi yang harus dilakukan daripada mengedepankan dialog dua arah. Kebanyakan solusi masih berasal dari guru, padahal sebagaimana yang disampaikan oleh Piaget bahwa anak- anak membangun pengetahuannya sendiri melalui interaksi dengan lingkungannya, dimana anak akan lebih mudah memahami sebuah pembelajaran apabila disajikan secara bermakna dam memberikan ruang bagi anak untuk menganalisa materi belajarnya. Proses membangun pengetahuan akan membantu anak untuk untuk lebih memahami setiap detil setiap pengetahuan yang dipelajari.

\section{SIMPULAN}

Sebagian besar guru- guru di kota malang telah memiliki persepsi yang tepat tentang pengembangan resolusi konflik sejak masa usia dini. Para guru berpandangan bahwa konflik pada masa usia dini adalah hal yang wajar sehingga tidak perlu disikapi dengan kepanikan. Namun, konflik pada anak juga hendaknya tidak dibiarkan. Guru maupun orang dewasa perlu membantu anak untuk dapat menyelesaikan konflik yang dihadapi hingga tuntas. Kehadiran guru dalam konflik yang terjadi diantara anak-anak akan membantu mereka mempelajari keterampilan hidup yang disebut dengan resolusi konflik. Persepsi guru ini akan mendasari perilaku mereka dalam mengembangkan kemampuan resolusi konflik anak usia dini.

Dalam aplikasinya guru-guru di kota malang telah menerapkan strategistrategi dalam mengembangkan kemampuan resolusi konflik pada anak usia dini, namun strategi strategi ini masih cenderung berpusat pada guru. Hendaknya guru mulai untuk melatih kemampuan pengembangan kemampuan resolusi konflik menggunakan pendekatan yang berpusat pada siswa. Pendekatan yang berpusat pada siswa akan lebih meningkatkan efektifitas dari pemahaman anak anak tentang bagaimana mengembangkan resolusi konflik.

\section{DAFTAR PUSTAKA}

Agarwal, Rita. 2000. "Tips For Tots." Early Childhood Consultant Partnership (860):6378. Retrieved November 29, 2020 (http://www.eccpct.com/Resources/Child/Tips-for-Tots/Help-YoungChildren-with-Conflict-Resolution/).

Alang, HM. Sattu. 2014. "Guru Yang Profesional Memiliki Kecerdasan Intelektual, Emosional, Dan Spiritual." Jurnal Bimbingan Penyuluhan Islam Al-Irsyad Al-Nafs.

Amini, Mukti. 2014. "Hakikat Anak Usia Dini." Perkembangan Dan Konsep Dasar Pengembangan Anak Usia Dini.

Anon. 2012. "Perkembangan Kecerdasan Emosi Kanak-Kanak Prasekolah Bermasalah Pendengaran: Implikasinya Terhadap Penglibatan Ibu Bapa 
(The Emotional Intelligence Development of Pre-Schoolers with Hearing Difficulties: Implications on Parental Involvement)." Akademika.

Dalimunthe, Syairal Fahmy. 2014. "Manajemen Konflik Dalam Organisasi." Palangka Raya Jurnal Studi Agama Dan Masyarakat. doi: 10.1007/s13398-014-0173-7.2.

Darmadi, Hamid. 2015. "Tugas, Peran, Kompetensi, Dan Tanggung Jawab Menjadi Guru Profesional." Pendidikan.

Eighty Six. 2014. "Preschool Social Skills_ Teaching Young Children How to Resolve Conflicts - BrightHub Education." Brighthub Education. Retrieved October 3, 2020 (https://www.brighthubeducation.com/teaching-preschool/128831preschool-conflict-resolution-through-play/).

Juwantara, Ridho Agung. 2019. "Analisis Teori Perkembangan Kognitif Piaget Pada Tahap Anak Usia Operasional Konkret 7-12 Tahun Dalam Pembelajaran Matematika." Al-Adzka: Jurnal Ilmiah Pendidikan Guru Madrasah Ibtidaiyah. doi: 10.18592/aladzkapgmi.v9i1.3011.

Khaironi, Mulianah. 2018. "Perkembangan Anak Usia Dini." Jurnal Golden Age Hamzanwadi University.

Lang, James M. 2016. "Small Changes in Teaching: The First 5 Minutes of Class." The Chronicle Of Higher Education.

Listyana, Rohmaul. 2015. "Persepsi Dan Sikap Masyarakat Terhadap Penanggalan Jawa Dalam Penentuan Waktu Pernikahan." Jurnal agastya vol 5 no 1 januari 2015 persepsi.

Ningsih, Euis. 2019. "Penggunaan Metode Bermin Peran Dalam Menumbuhkan Keterampilan Berbahasa Anak Usia Dini." Empowerment.

Nurjannah, Nurjannah. 2017. "Mengembangkan Kecerdasan Sosial Emosional Anak Usia Dini Melalui Keteladanan." Hisbah: Jurnal Bimbingan Konseling Dan Dakwah Islam. doi: 10.14421/hisbah.2017.141-05.

Parenting, Parenting. 2020. "Ingat, Bullying Juga Bisa Dialami Oleh Anak TK Dan SD! - School of Parenting." School of Parenting. Retrieved (https://schoolofparenting.id/ingat-bullying-juga-bisa-dialami-oleh-anaktk-dan-sd/).

Riyanto, Buddy. 2019. "Media Sosial Dan Multikulturalisme Dikalangan Pemuda Surakarta." ETTISAL: Journal of Communication. doi: 10.21111/ettisal.v4i1.3070.

Sa'diyah, Rika. 2018. "Urgensi Kecerdasan Emosional Bagi Anak Usia Dini." Cakrawala Dini: Jurnal Pendidikan Anak Usia Dini 4(1):1-19. doi: 10.17509/cd.v4i1.10375.

Setiawan, Samhis. n.d. "Pengertian Persepsi, Ciri, Jenis, Faktor, Proses Dan Contoh." 2019.

Sudrajat, Sudrajat. 2014. "Revitalisasi Pendidikan Multikultural Dalam Pembelajaran." Jurnal Pembangunan Pendidikan: Fondasi Dan Aplikasi. doi: 10.21831/jppfa.v2i1.2620.

Wahyudi, Andri. 2015. "Konflik, Konsep Teori Dan Permasalahan." Jurnal Publiciana.

Wardyaningrum, Damayanti. 2013. "Komunikasi Untuk Penyelesaian Konflik Dalam Keluarga: Orientasi Percakapan Dan Orientasi Kepatuhan." Jurnal Al-Azhar Indonesia Seri Pranata Sosial. 
AWLADY: Jurnal Pendidikan Anak

Homepage: www.syekhnurjati.ac.id/jurnal/index.php/awlady

p-ISSN: 2541-4658 e-ISSN: 2528-7427

Vol. 7, No 1 March (2021)

Zuchdi, Darmiyati. 1995. "Pembentukan Sikap." Jurnal Cakrawala Pendidikan. doi: 10.21831/cp.v3i3.9191. 